\title{
Evaluation of Culture Medium for Human Keratinocytes
}

\author{
Fabiana Regina Xavier Batista ${ }^{1 *}$, Jussara Rehder ${ }^{2}$ and Maria Beatriz Puzzi
}

${ }^{1}$ School of Chemical Engineering, Federal University of Uberlandia, Uberlandia, Minas Gerais, Brazil.

${ }^{2}$ Skin Cell Culture Laboratory, Center for Investigation in Pediatrics, State University of Campinas Medical School, Campinas, São Paulo, Brazil

\begin{abstract}
Human keratinocytes are needed for tissue engineering of skin applied in tissue repair and regeneration aimed at clinical application. The need to have high cell concentrations within a short time when performing cell proliferation is vital. The growth and maintenance of these cells commonly involve the use of MCDB 153 medium, which is supplemented with animal-derived components, such as growth factors and fetal bovine serum (FBS). The aim of this work was to evaluate different formulations based on MCDB 153 medium for keratinocyte proliferation. For that, several experiments were realized to define which supplements are important for skin cell culture using $2^{4}$ factorial design. Skin samples were obtained from four consenting patients submitted to dermolipectomy, the plastic surgery operation. These fragments were treated with $0.25 \%$ trypsin-EDTA for four hours, at $37^{\circ} \mathrm{C}$. Furthermore, the epidermis was separated from the dermis, providing skin cells. Batch cultures were performed in 6 and 96 -well plates, in addition to $25 \mathrm{~cm}^{2}$ flasks. Results concerning cell growth and metabolism showed that keratinocytes were full grown up in MCDB 153 medium containing insulin $\left(7.5 \mu \mathrm{g} \cdot \mathrm{mL}^{-1}\right)$, bovine pituitary extract-BPE $\left(80 \mu \mathrm{g} \cdot \mathrm{mL}^{-1}\right)$, epidermal growth factor-EGF $\left(0.08 \mu \mathrm{g} \cdot \mathrm{mL}^{-1}\right)$, hydrocortisone $\left(0.63 \mu \mathrm{g} \cdot \mathrm{mL}^{-1}\right)$ and glutamine $\left(1 \mathrm{~g} \cdot \mathrm{L}^{-1}\right)$. On the other hand, culture media proposed in the experimental design did not resulted in satisfactory cell growth. In addition, although, the initial glucose concentration was low in the most of cases, the lactate was strongly produced by cells reaching $1 \mathrm{~g} \cdot \mathrm{L}^{-1}$.
\end{abstract}

Keywords: Skin; Keratinocytes; MTT assay; Factorial design; Metabolism

\section{Introduction}

Human skin is an organ that allows life by regulating heat and water loss from the body, while preventing the ingress of noxious chemicals or microorganisms. Healthy human skin consists of three main layers: subcutaneous tissue (stratified), underlying dermis and cellular epidermis $[1,2]$.

The subcutaneous fat layer is found between the overlying dermis and the underlying body constituents. This adipose tissue provides mechanical protection against physical shock, and it can also provide an available supply of high-energy molecules. The dermis, which is normally $4 \mathrm{~mm}$ thick, is the major component of human skin. It is composed of a connective tissue, predominantly collagen fibers produced by fibroblasts, providing support and flexibility. This layer also has several structures embedded within it, blood and lymphatic vessels, nerve endings, hair follicles, sebaceous glands and sweat glands. The epidermis itself is a complex multiple layered membrane, containing no blood vessels and, hence, nutrients and waste products must diffuse across the dermo-epidermal layer in order to maintain tissue integrity. Epidermis contains keratinocytes close to the stratum germinativum (basal layer), and these ensure its regeneration. It also contains melanocytes, cells responsible for skin pigmentation and melanin synthesis.

When a lesion occurs, the skin repairs itself through the proliferation and growth of dermal and epidermal cells [3]. In deep skin lesions, destruction of the dermal and epidermal elements may occur. This makes the regeneration process slow and subject to complications. In such cases, autologous skin transplantation may be used, but its use is limited by the extent of the donor site and by the patient's clinical condition. Allotransplants from cadavers or volunteers are rejected after one or two weeks and provide only temporary coverage. Hence, studies have been conducted with the aim of solving the problem of the need for large amounts of skin for transplantation in cases of burn victims and chronic skin ulcer $[4,3,5]$.

Some authors described a skin substitute used in the burn trauma treatment [6]. This material has been developed for the reconstruction of dermal structures and is designed as a bilayer. It consists of a modified bovine collagen matrix and a silastic membrane facing toward the body surface. However, biocompatible materials as adhesives or curatives can cause pain when administered under the wound; therefore, local anesthesia is required.

The first step for production of reconstructed skin involves the proliferation of dermal (fibroblasts) and epidermal cells (keratinocytes and melanocytes). As a huge amount of fibroblasts is needed for engineering of skin, the need to have high cell concentration within a short period of time is essential [7]. After the proliferation of fibroblasts, the collagen tissue may be used as matrix for cultured growth, and it provides a dermal equivalent with characteristics very similar to those found in human dermis in vivo [8]. Finally, human keratinocytes and melanocytes are plated on this collagen matrix.

For the treatment of large skin defects, a higher number of viable fibroblasts and keratinocytes are needed [7]. For human keratinocyte media formulations, factors such as insulin, transferrin and lipid emulsion (containing cholesterol, $\alpha$-tocopherol acetate, fatty acids, Tween 80, and Pluronic F-68) should be evaluated.

Insulin is a polypeptide of 5700 molecular weight that affects cell metabolism, although it is thought that its main effect is on glucose metabolism [9]. Transferrin is an iron transport protein and almost every cell line shows a positive response to its presence in the medium [9]. Lipids and fatty acids act as precursors for prostaglandin synthesis and represent an alternative energy source, compounding

*Corresponding author: Fabiana Regina Xavier Batista, School of Chemical Engineering, Federal University of Uberlandia, Uberlandia, Minas Gerais, Brazil. Tel: + 5534 32394291; Fax: + 5534 3239-4188; E-mail: frxbatista@feq.ufu.br

Accepted November 21, 2010; Published November 24, 2010

Citation: Xavier Batista FR, Rehder J, Puzzi MB (2010) Evaluation of Culture Medium for Human Keratinocytes. J Stem Cell Res Ther 1:101. doi:10.4172/21577633.1000101

Copyright: (C) 2010 Xavier Batista FR, et al. This is an open-access article distributed under the terms of the Creative Commons Attribution License, which permits unrestricted use, distribution, and reproduction in any medium, provided the original author and source are credited 
the cell membrane. Other supplements can also be used, such as EGF, BPE, hydrocortisone, ethanolamine, sodium selenium, sodium pyruvate and aurintricarboxylic acid (ATA). These supplements are capable of maintaining cell viability, in addition to support cell growth.

The present work evaluates the growth and metabolic performance of human keratinocytes, potentially used for skin reconstruction, in different media. These media were formulated using a statistical method, involving factorial design. This methodology can be employed to identify factors with significant effects on the response, interactions among these factors and which of these factors have the most important effects on the response. In addition, this method can be used to investigate the functional dependence of a response on multiple factors simultaneously, testing several levels of each factor [10]. Finally, the culture media evaluated through this methodology can represent a possibility to sustaining cell proliferation and differentiation aimed clinical application.

\section{Materials and Methods}

\section{Media, supplements and other reagents}

Keratinocyte SFM, KCM (Invitrogen Co., USA) and MCDB 153 (Sigma Co., USA) were used. Supplements as insulin, transferrin, ATA, sodium pyruvate, sodium selenium and hydrocortisone from Sigma, BPE, EGF and FBS from Invitrogen were also used. The components as MTT, [3-(4,5-dimethylthiazol-2-yl)-2,5-diphenyltetrazolium bromide] from Sigma, $0.9 \% \mathrm{NaCl}$ physiological solution (Halexlstar Ind.) and both conjunction penic illin-streptomycin-glutamine (10 000 units of penicillin; $10,000 \mu \mathrm{g}$ of streptomycin, and $29.2 \mathrm{mg}$ of L-glutamine. $\mathrm{mL}^{-1}$ in $0.85 \%$ saline) and antibiotic-antimycotic solution (10 000 units of penicillin, $10000 \mu \mathrm{g}$ of streptomycin, and $25 \mu \mathrm{g}$ of amphotericin B in $0.85 \%$ saline) were purchased from Invitrogen. In addition, $0.25 \%$ trypsin-EDTA solution and SDS both from Invitrogen and $\mathrm{HCl}$ (Merse Darmstadt, Germany) were used.

\section{Isolation of cells from skin tissue samples}

Skin samples were obtained from four consenting patients submitted to dermolipectomy surgery at the State University of Campinas Teaching Hospital. This procedure was in accordance with the Ethics Committee of State University of Campinas Medical School, Brazil. The material was placed in sterile tempered glass jars (Duran, Germany), conserved in $0.9 \% \mathrm{NaCl}$ physiological solution containing antibiotic-antimycotic solution $(0.01 \%)$ and refrigerated at $4^{\circ} \mathrm{C}$, without exceeding a limit of 12 hours until its manipulation.

The skin fragments were separated from the adipose tissue, placed on a Petri dish (Corning Inc., USA) and sectioned into small pieces of 5 to $10 \mathrm{~mm}$, using surgical instruments under a laminar flow. Afterwards, these fragments were treated with $0.25 \%$ trypsinEDTA solution and incubated at $37{ }^{\circ} \mathrm{C}$, with $5 \% \mathrm{CO}_{2}$ tension for four hours. Subsequently, the trypsin solution was neutralized by MCDB 153 medium containing $20 \%$ FBS, and the material was filtered using a $40 \mu \mathrm{m}$ nylon filter $($ Falcon $\AA$ ). This procedure resulted in a separation of epidermis (containing keratinocytes and melanocytes) from dermis (containing fibroblasts and collagen fibers), providing skin cells.

\section{Skin cell culture}

Keratinocytes were maintained in Keratinocyte SFM (KCM) at $37^{\circ} \mathrm{C}$ and $5 \% \mathrm{CO}_{2}$ using $25 \mathrm{~cm}^{2}$ flasks (TPP AG, Switzerland). The medium was replaced every 48 hours to avoid lack of nutrients and accumulation of toxic metabolites.

\section{Evaluation of medium supplements on cell growth, viability, and metabolism}

Basically, this study consisted of the evaluation of media for human keratinocytes using statistical method and also a preliminary investigation of cell metabolism. The analysis of the effects of insulin ( 1 to $10 \mathrm{mg} \cdot \mathrm{mL}^{-1}$ ) and transferrin (1 to $5 \mathrm{mg} \cdot \mathrm{mL}^{-1}$ ) concentrations, as well as lipid emulsion percentage (1 to $3 \%$ ) on the viability was performed through a $2^{3}$ factorial experimental design, in a total of 12 experiments, as indicated in Table 1 . Supplements as sodium selenium (50 nmol. $\left.\mathrm{L}^{-1}\right)$, glutamine $\left(1 \mathrm{~g} . \mathrm{L}^{-1}\right)$, ethanolamine $\left(50 \mu \mathrm{mol} . \mathrm{L}^{-1}\right)$, hydrocortisone $\left(0.63 \mu \mathrm{g} \cdot \mathrm{mL}^{-1}\right)$, BPE $\left(80 \mu \mathrm{g} \cdot \mathrm{mL}^{-1}\right)$ and EGF $(0.008 \mu \mathrm{g}$. $\mathrm{mL}^{-1}$ ) were also added to MCDB 153 basal medium. The range of concentrations selected for these supplements is in agreement with regular skin cell culture practice. Experiments were carried out in 96-well plates and the initial cell concentration was $1 \times 10^{5}$ viable cells. $\mathrm{mL}^{-1}$. Control assays were performed in $\mathrm{KCM}$. The response was viability evaluated by MTT methodology. The statistical effects were calculated using the software Statistica 5.0 (StatSoft Co.). The significance level of $\mathrm{P}<0.05$ was assumed for viability.

Subsequently, human keratinocytes were adapted on the formulations 3 (F3), 4 (F4) and 7 (F7) from factorial design cited before, using 6 -well plates, since the best results to viability were obtained under these conditions. In the cell adaptation process, the conditioned medium was removed each 48 -hour period and the fresh medium was added. This procedure was performed during seven days and then an enzymatic treatment (0.25\% trypsin-EDTA) was performed for maximum cell growth determination.

In order to increase maximum cell concentrations and to avoid cell morphological changes, the selected formulation (F3) was modified. The insulin concentration was reduced from $1 \mathrm{mg}$. $\mathrm{mL}^{-1}$ to $7.5 \mu \mathrm{g} \cdot \mathrm{mL}^{-1}[4,7]$, while lipid emulsion (3\%), hydrocortisone $(0.63 \mu \mathrm{g}$. $\left.\mathrm{mL}^{-1}\right)$ and BPE $\left(80 \mu \mathrm{g} \cdot \mathrm{mL}^{-1}\right)$ concentrations were fixed. However, other supplements were deleted. MTT was reduced by cells cultured under this condition and in the control assay (KCM).

\section{Analytical Methods}

Cell number and viability were determined using trypan blue exclusion (1:2 v/v mixture of cell sample and $0.4 \%$ trypan blue) using a hemocytometer (improved Neubauer, Brand). Glucose and lactate concentrations were analyzed using the YSI 2700 analyzer (Yellow Spring Instruments, USA).

The viability was estimated by MTT assay [11]. Briefly, the cells maintained in KCM were inoculated in 96-well plates at $1 \times 10^{5}$ cells. $\mathrm{mL}^{-1}$. After 24 hours, the supernatant was removed and the cells were washed with PBS (0.05 mol. $\mathrm{L}^{-1}$ and $\mathrm{pH}$ of 7-7.2). Afterwards, the tested

\begin{tabular}{|l|l|l|l|l|}
\hline \multicolumn{4}{|l|}{ Independent variables } & Dependent variable \\
\hline Formulation & $\begin{array}{l}\text { Insulin } \\
\left(m g \cdot m L^{-1}\right)\end{array}$ & $\begin{array}{l}\text { Lipid Emulsion } \\
(\%)\end{array}$ & $\begin{array}{l}\text { Transferrin } \\
\left(m g \cdot m L^{-1}\right)\end{array}$ & $\begin{array}{l}\text { Viability } \\
(\%)\end{array}$ \\
\hline 1 & 1 & 1 & 1 & 57 \\
\hline 2 & 10 & 1 & 1 & 64 \\
\hline 3 & 1 & 3 & 1 & 92 \\
\hline 4 & 10 & 3 & 1 & 90 \\
\hline 5 & 1 & 1 & 5 & 69 \\
\hline 6 & 10 & 1 & 5 & 60 \\
\hline 7 & 1 & 3 & 5 & 91 \\
\hline 8 & 10 & 3 & 5 & 78 \\
\hline 9 & 5 & 2 & 3 & 82 \\
\hline 10 & 5 & 2 & 3 & 78 \\
\hline 11 & 5 & 2 & 3 & 79 \\
\hline Control & n.a. & n.a. & n.a. & 95 \\
\hline
\end{tabular}

Formulations 9 to 11 correspond to central points, $\mathrm{n}$ a: not added. Control: Keratinocyte SFM (KCM)

Table 1: $2^{3}$ factorial design for insulin, transferrin and lipid emulsion supplements. 
Citation: Xavier Batista FR, Rehder J, Puzzi MB (2010) Evaluation of Culture Medium for Human Keratinocytes. J Stem Cell Res Ther 1:101. doi:10.4172/2157-7633.1000101

media $(100 \mu \mathrm{L})$ were added. After 48 hours, $10 \mu \mathrm{L}$ MTT solution $(5$ $\mathrm{mg} \cdot \mathrm{mL}^{-1}$ in PBS) was added to each well and the plates, covered with aluminum foil, were incubated at $37^{\circ} \mathrm{C}$ for four hours. SDS $(5 \% \mathrm{~m} / \mathrm{v})$ prepared in $\mathrm{HCl}(0.01 \mathrm{~N})$ was also added at $50 \mu \mathrm{L}$ per well followed by overnight, at room temperature, to completely dissolve formazan crystals. Absorbance was measured at $570 \mathrm{~nm}$, using a microplate reader (Multiskan MS, Thermo Labsystem, USA). The influence of tested media on the MTT reduction in the absence of cells was also determined.

Yield coefficient of cell $\left(Y_{x g l c}\right)$ and lactate $\left(Y_{\text {lacglc }}\right)$ from glucose were determined using the following equations:

$$
\begin{gathered}
Y_{x / g l c}=\frac{\Delta X}{-(\Delta G)} \\
Y_{l a c / g l c}=\frac{\Delta L}{-(\Delta G)}
\end{gathered}
$$

Where $\mathrm{X}$ is the cell concentration, $\mathrm{G}$ and $\mathrm{L}$ are glucose and lactate concentrations, respectively. For the yield coefficient calculation, two time points were considered: one was immediately after inoculation, and the final point was at the inset of exponential phase, typically after 72 hours. Yield is the ratio of amount produced per amount consumed for any product/reactant pair.

\section{Results and Discussion}

\section{Effects of insulin, lipid emulsion and transferrin on the human keratinocyte viability in serum-free medium}

High concentrations of skin cells are required for tissue repair technology, such as reconstructed skin. For this purpose, nutritive cell media, as well as adequate physiological conditions may be provided. However, the development of cell culture medium is a complex process, involving the adjustment of numerous interactive components to their optimal concentrations with a goal of strong consistent support of cell growth. Figure 1 presents morphological characteristics of skin cells.

Statistical methods for developing the best medium formulation for maximizing cell production are a well-established practice
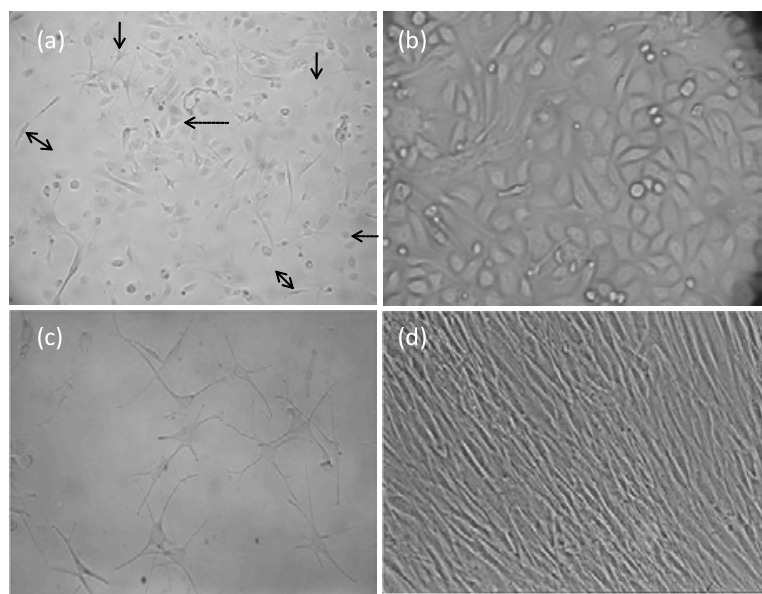

Figure 1: Morphological characteristics of epithelial (b, c) and fibroblastic (d) cells growing out from human skin biopsies. (a) Primary culture of skin cells including keratinocytes $(\rightarrow)$, melanocytes $(\rightarrow)$ and fibroblasts $(\leftrightarrow)$. The cells were maintained in (b) KCM, (c) MCDB 153 medium with FBS $(10 \%$ ), insulin $\left(30 \mu \mathrm{g} \cdot \mathrm{mL}^{-1}\right)$, hydrocortisone $\left(0.63 \mu \mathrm{g} \cdot \mathrm{mL}^{-1}\right)$ e BPE $\left(62.5 \mu \mathrm{g} \cdot \mathrm{mL}^{-1}\right)$ and (d) MCDB 153 medium with $10 \%$ FBS. Optical microscopy $(40 \mathrm{X})$. The culture conditions considering two distinct instants of cultivation: (a) and (c) 72 hours after tissue digestion, (b) and (d) the end of exponential phase (confluence).

\begin{tabular}{|l|l|l|l|l|l|}
\hline Source of Variance & Sum of Squares & $\begin{array}{l}\text { Degree of } \\
\text { Freedom }\end{array}$ & Mean Squares & F & $\mathbf{F}_{\text {tab }}$ \\
\hline Regression & 1275.13 & 1 & 1275.13 & 43.6 & 5.12 \\
\hline Residual & 263.42 & 9 & 29.27 & & \\
\hline Lack of Fit & 163.63 & 6 & & & \\
\hline Pure error & 99.79 & 3 & & & \\
\hline Total & 1538.75 & 10 & & & \\
\hline
\end{tabular}

Table 2: ANOVA for $2^{3}$ factorial design on viability.

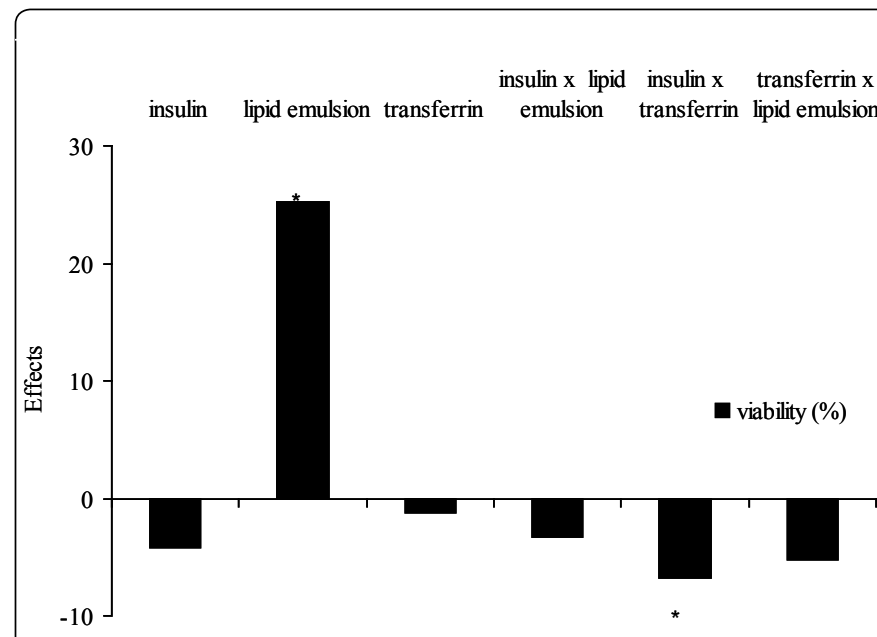

Figure 2: Statistical effects obtained for the $2^{3}$ factorial design on the viability. *Indicates that the variable is statistically significant at $95 \%$ confidence.

$[12,13,14]$. In our analysis, a main effect of outcome is a consistent difference between levels of variables of the factors insulin, lipid emulsion and transferrin on the viability.

In the first step taken towards developing a serum-free medium for human keratinocytes, the $2^{3}$ factorial design with three central points was employed. The effects of insulin (1 to $\left.10 \mathrm{mg} \cdot \mathrm{mL}^{-1}\right)$, lipid emulsion (1 to $3 \%$ ) and transferrin (1 to $5 \mathrm{mg} \cdot \mathrm{mL}^{-1}$ ) on the viability were evaluated. The results were indicated in Table 1 , while the calculated statistical effects are shown in Figure 2. In addition, Table 2 presents the analysis of variance (ANOVA).

As shown in Table 2 and Figure 2, statistically significant effect on viability was observed for lipid emulsion (according to linear regression and analysis of variance, the calculated $\mathrm{F}$ value was 43.6 , i.e. more than 8.5 times higher than the listed value, equal to 5.12) and synergetic interaction from insulin and transferrin.

In the present work, lipid emulsion (chemically defined lipid concentration) containing cholesterol and some fatty acids (arachidonic, linoleic, linolenic, myristic, oleic, palmitic and stearic acids) scattered into Pluronic F68 ${ }^{\circledR}$ and Tween 20 was used. In general, lipids as cholesterol and fatty acids are essential for mammalian cell growth $[9,11]$. In addition, in a free-state or bound to carries like albumin or lipoprotein, lipids act as precursors for prostaglandin synthesis, representing an alternative energy source and are major components of the cell membrane [9]. In addition, other researchers [15] observed that human keratinocytes cultured in serum-free medium become fatty acid deficient.

The cholesterol content was related to the ability of keratinocytes to synthesize the cornified envelope, which is one of the most characteristic features of keratinocyte differentiation [16]. Concerning lipid metabolism in cultured keratinocytes, the authors also showed that epidermal lipogenesis, both in vivo and in vitro, depends on the balance between cellular requirements and access to the exogenous lipid supply in vivo. Hence, medium supplemented with lipid is essential. 
Citation: Xavier Batista FR, Rehder J, Puzzi MB (2010) Evaluation of Culture Medium for Human Keratinocytes. J Stem Cell Res Ther 1:101. doi:10.4172/2157-7633.1000101

(a)

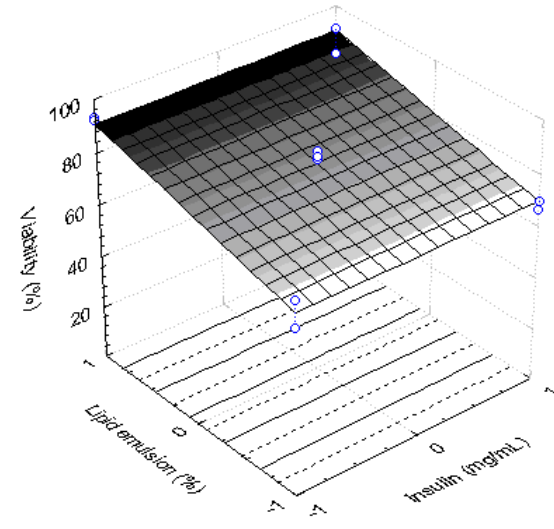

(b)

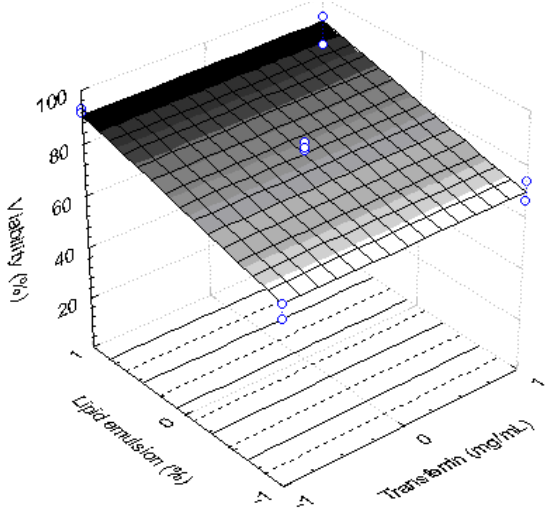

Figure 3: Response surfaces of viability as a function of insulin concentration and lipid emulsion percentage (a) transferrin concentration and lipid emulsion percentage (b).

As shown in Figure 2, increases on the lipid emulsion percentage increased the keratinocyte viability. Nevertheless, isolated concentrations of insulin and transferrin have not presented significant effects on the response.

Since lipid emulsion presented a statistically significant effect on the viability, a mathematical model (Eq. 3) was generated to describe this response to variable behavior as a function of lipid emulsion percentage. The coded model was used to generate the correspondent response surfaces, as shown in Figure 3. These diagrams (Figure 3a and $3 \mathrm{~b}$ ) indicated that a lipid emulsion percentage at $3 \%$ (level +1 ) can be considering the most advantageous condition to achieve high viability.

$$
V=76.4-12.6 C_{\text {lipidemulsion }}-3.7 C_{\text {lipidemulsion }} C_{\text {transferrin }}
$$

\section{Performance of human keratinocytes on F3, F4 and F7}

As observed in Table 1, viability above $90 \%$ was obtained by keratinocytes maintained in F3, F4 and F7 from $2^{3}$ fractional design. Therefore, the cells were cultured in these formulations using 6-well plates for metabolic analysis. The inoculum was prepared in KCM and after 24 hours tested media (F3, F4 and F7) were added. The results are shown in Table 3.

The best performance with reference to the cell growth was obtained by keratinocytes cultured in F3 $\left(2.5 \pm 0.17 \times 10^{5}\right.$ cells. $\left.\mathrm{mL}^{-1}\right)$, when compared with the control assay in $\mathrm{KCM}\left(3.0 \pm 1.3 \times 10^{5}\right.$ cells.
$\mathrm{mL}^{-1}$ ). The cell growth practically was not observed in $\mathrm{F} 4$, whilst keratinocytes died in F7 after adding medium.

The simple comparison among the tested media (F3, F4 and F7) suggested that transferrin concentrations (above $1 \mathrm{mg} \cdot \mathrm{mL}^{-1}$ ) were probably above the required. The results showed that at $5 \mathrm{mg} \cdot \mathrm{mL}^{-1}$ (F7) the transferrin concentration can cause cell death. Iron is believed to be essential for animal cells, and transferrin is the main carrier for stabilizing and presenting iron and trace elements in the cell [11]. However, at high concentrations, this supplement showed itself toxic for human keratinocytes.

Since the higher maximum cell concentration was obtained for F3, it was observed increase in cell size and the presence of lumpiness (data not shown). Hence, the apparent viability (Table 3) was used to measure capacity of living, under evaluated conditions, since it was not observed cells stained blue after trypan blue dye exclusion method. Thus, changes in media formulation were performed to avoid morphological cell modifications, such as reduction and deletion of supplements.

In fact, several experiments were necessary to define which supplements are important for skin cell culture (data not shown). When insulin concentration was reduced and some components (transferrin, sodium selenium and ethanolamine) were deleted from F3, it was observed satisfactory cell growth. MCDB 153 supplemented with insulin $\left(7.5 \mu \mathrm{g} . \mathrm{mL}^{-1}\right)$, lipid emulsion $(3 \%)$, hydrocortisone $(0.63 \mu \mathrm{g}$. $\left.\mathrm{mL}^{-1}\right)$ and BPE $\left(80 \mu \mathrm{g} \cdot \mathrm{mL}^{-1}\right)$, called modified F3, was evaluated for cell culture. Figure 4 summarizes the results.

In this experiment (Figure 4), using MTT methodology, it can observed that mitochondria were capable of maintaining activity in modified F3 medium, similarity at control in KCM. It suggested that this formulation could provide cell proliferation, although further experiments should be performed to confirm these findings.

Concerning the cell metabolism, two of the most commonly

\begin{tabular}{|c|c|c|c|c|}
\hline Medium & $\begin{array}{l}\text { Maximum Cell } \\
\text { Concentration } \\
\left(10^{5} \text { cells. } \mathrm{mL}^{-1}\right)\end{array}$ & $\begin{array}{l}\text { Viability } \\
(\%)\end{array}$ & $\begin{array}{l}Y_{X / g l c} \\
\left(10^{8} \text { cells. } g_{g / c}{ }^{-1}\right)\end{array}$ & $\begin{array}{l}\boldsymbol{Y}_{\text {glc/lac }} \\
\left(\boldsymbol{g}_{\text {glc }} \cdot \boldsymbol{g}_{\text {lad }}\right)\end{array}$ \\
\hline F3 & $2.5 \pm 0.17$ & $99 \pm 0.6^{*}$ & $1.63 \pm 0.81$ & $1.13 \pm 0.20$ \\
\hline F4 & $1.2 \pm 0.09$ & $99 \pm 0.08$ * & $0.23 \pm 0.09$ & $1.14 \pm 0.06$ \\
\hline F7 & $0.6 \pm 0.13$ & $99 \pm 0.11^{*}$ & n.d. & $1.11 \pm 0.13$ \\
\hline control & $3.0 \pm 1.3$ & $99 \pm 0.89$ & $2.2 \pm 0.11$ & $0.84 \pm 0.08$ \\
\hline
\end{tabular}

Control: Keratinocyte SFM (KCM); the inoculum was prepared in $\mathrm{KCM}$; *indicates the apparent viability; $n$.d. indicates not determined; results represent the average of two independent experiments with three trials each

Table 3: Comparison among growth variables of keratinocytes maintained in different formulations.

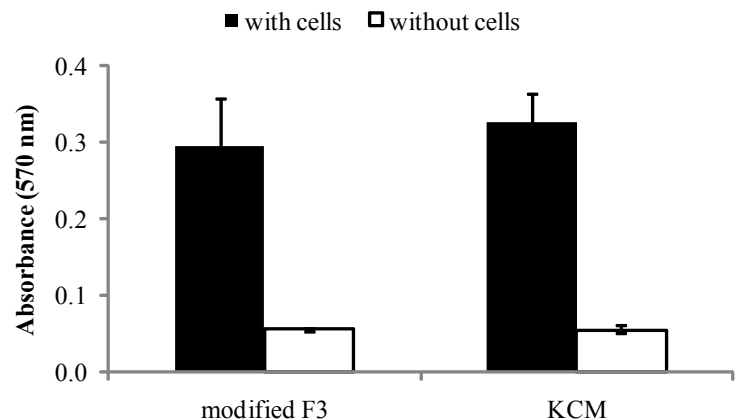

Figure 4: MTT reduction by tested medium after 48 hours of incubation at $37^{\circ} \mathrm{C}$ and $5 \% \mathrm{CO}_{2}$. The results represent the average of two independent experiments with three trials each. KCM was used as control. 
Citation: Xavier Batista FR, Rehder J, Puzzi MB (2010) Evaluation of Culture Medium for Human Keratinocytes. J Stem Cell Res Ther 1:101. doi:10.4172/2157-7633.1000101

Page 5 of 5

compounds in animal cell culture (glucose and lactate) were monitored. Glucose serves as both a main carbon source and an important energy source in most medium formulation. Entry of glucose into glycolytic pathway leads to the formation of pyruvate as end product. In animal cells, pyruvate can either be shuttled into TCA cycle or be converted into lactate [17]. However, the influence of lactate accumulation on these cultures has rarely been examined.

Glucose, present in basal medium (MCDB 153) at 1 g. $\mathrm{L}^{-1}$, was totally consumed by cells after 96 hours, while lactate was produced during cell culture. Results showed that the glucose-to-cell yield coefficient provided by F3 was 7-fold higher (Table 3$)$ than that by F4 $(0.23 \mathrm{x}$ $10^{8}$ cells. $\left.\mathrm{g}_{\mathrm{glc}}{ }^{-1}\right)$. Although, the glucose-to-lactate yield coefficient $\left(\mathrm{Y}_{\mathrm{lac}}\right.$ ${ }_{\mathrm{glc}}$ ) was similar in both conditions, around $1.13 \mathrm{~g}_{\mathrm{lac}} \cdot \mathrm{g}_{\mathrm{glc}}{ }^{-1}$.

High values to $\mathrm{Y}_{\text {lac/glc }}$ for keratinocytes maintained in tested formulation indicate that cells proliferated in vitro (at low passages) have deregulated glucose metabolism. In other words, cells produce preferably lactate in the glycolytic pathway. Increases in $\mathrm{Y}_{\text {lacklc }}$ and glucose concentration in mammalian cell cultures (hybridoma) were observed [18]; however, inhibition occurs at concentration which usually is not reached during growth.

The maximum lactate concentration was around $1 \mathrm{~g} \cdot \mathrm{L}^{-1}$; however, the lactate can cause growth inhibition in mammalian cells above of 3.6g. $\mathrm{L}^{-1}[19]$. Our findings are consistent with a current literature [20], which observed that keratinocytes cultured in EpiLife Keratinocyte Medium containing human keratinocyte growth supplement (HKGS), BPE $(0.2 \% \mathrm{v} / \mathrm{v})$ and soy protein hydrolysates $\left(1 \mathrm{~g} . \mathrm{L}^{-1}\right)$ consumed up to 0.7 g. $\mathrm{L}^{-1}$ of glucose and produced 0.9 g.. $\mathrm{L}^{-1}$ of lactate in 96 hours.

Finally, other researchers reported that the glucose-to-cell yield coefficient in a culture of human epithelial cells (hTERT-HME1) was $2.8 \times 10^{8}$ cells. $\mathrm{g}_{\mathrm{glc}}{ }^{-1}$, which is comparable to the value determined in the present study $\left(1.6 \times 10^{8}\right.$ cells. $\left.{ }_{\mathrm{glc}}{ }^{-1}\right)$ [21]. However, the value of cell growth coefficients is known to vary depending on culture phases and conditions.

\section{Conclusion}

According to this study, among the formulations evaluated in the factorial design only F3, F4 and F5 provide satisfactory results with cell proliferation. Human keratinocytes cultured in modified F3 demonstrated similar growing capacity $\left(2.5 \times 10^{5}\right.$ cell. $\left.\mathrm{mL}^{-1}\right)$ concerning the Keratinocyte SFM $(\mathrm{KCM}),\left(3 \times 10^{5}\right.$ cell. $\left.\mathrm{mL}^{-1}\right)$. The metabolic analysis shows that even in low initial concentrations of glucose, high lactate concentration were observed. This is an essential result for the future of tissue-engineered skin. However, further investigations are necessary for a more detailed interpretation of this finding.

\section{Acknowledgments}

We thank the Fundação de Amparo a Pesquisa do Estado de São Paulo (grants numbers 07/55063-6 and 07/54655-7) and the Coordenação de Aperfeiçoamento de Pessoal de Ensino Superior for supporting this work. The authors are also grateful to Dr. Ronaldo Zucatelli Mendonça (Butantan Institute, Brazil) for glucose and lactate measurements, Prof. Dr. Antonio Condino Neto (University of São Paulo) for infrastructure support, Prof. Dr. Elinton Adami Chain (State University of Campinas Medical School) and your research group for providing skin samples, and Prof. Dr Ângela Maria Moraes and Dr. Oselys Rodriguez Justo (both from the School of Chemical Engineering, State University of Campinas, Brazil) for technica expertise and advice during the course of this study.

\section{References}

1. Williams A (2003) Transdermal and topical drug delivery: from theory to clinical practice in The Annals of Pharmacotherapy, Pharmaceutical Press, London, England.

2. McGrath JA, Eady RAJ, Pope FM (2004) Anatomy and Organization of Human skin. Rook's Textbook of Dermatology, Seventh Edition, Blackwell Publishing, USA 3.1-3.6.

3. Souto LR, Vassallo J, Rehder J, Pinto GA, Puzzi MB (2009) Immunoarchitectural characterization of a human skin model reconstructed in vitro. Sao Paulo Med J 127: 28-33.

4. Rehder J, Souto LRM, Issa CMBM, Puzzi MB (2004) Model of human epidermis reconstructed in vitro with keratinocytes and melanocytes on dead de-epidermized human dermis. Sao Paulo Med J 122: 22-25.

5. Souto LRM, Rehder J, Vassallo J, Cintra ML, Kraemer MHS, et al. (2006) Model for human skin reconstructed in vitro composed of associated dermis and epidermis. Sao Paulo Med J 124: 71-76.

6. Wisser D, Steffes J (2003) Skin replacement with a collagen based derma substitute, autologous keratinocytes and fibroblasts in burn trauma. Burns 29 375-380.

7. Mazlyzam AL, Aminuddinn BS, Saim L, Ruszymah BHI (2008) Human Serum is an Advantageous Supplement for Human Dermal Fibroblast Expansion: Clinical Implications for Tissue Engineering of Skin. Arch Med Res 39: 743-752.

8. Vaissiere G, Chevallay B, Herbage D, Damour O (2000) Comparative analysis of different collagen-based biomaterials as scaffolds for long-term culture of human fibroblasts. Med Biol Eng Comput 38: 205-210.

9. Hewlett G (1991) Strategies for optimising serum-free media. Cytotechnology 5: 3-14.

10. Box GE, Hunter JS, Hunter WG (2005) Statistics for Experimenters: Design Innovation and Discovery, $2^{\text {nd }}$ Edition, Wiley, Hoboken, NJ, USA.

11. Chen Z, Iding K, Lütkemeyer D, Lehmann J (2000)A low cost chemically defined protein free medium for a recombinant $\mathrm{CHO}$ cell line producing prothrombin Biotechnol Lett 22: 837-841.

12. Ikonomou L, Schneider YJ, Agathos SN (2003) Insect cell culture for industrial production of recombinant proteins. Appl Microbiol Biotechnol 62: 1-20.

13. Batista FR, Pereira CA, Mendonça RZ, Moraes AM (2005) Enhancement of Sf9 cells and Baculovirus production employing Grace's medium supplemented with milk whey ultrafiltrate. Cytotechnology 49: 1-9.

14. Batista FR, Pereira CA, Mendonça RZ, Moraes AM (2008) Formulation of a protein-free medium based on IPL-41 for the sustained growth of Drosophila melanogaster S2 cells. Cytotechnology 57: 11-22.

15. Wey HE, Pyron L, Woolery M (1993) Essential fatty acid deficiency in cultured human keratinocytes attenuates toxicity due to lipid peroxidation. Toxicol App Pharmacol 120: 72-79

16. Taube MBP, Taieb A (2000) Lipid metabolism in cultured keratinocytes. An Bras Dermatol 75: 75-84.

17. Tsao YS, Cardoso AG, Condon RG, Voloch M, Lio P (2005) Monitoring Chinese hamster ovary cell culture by the analysis of glucose and lactate metabolism. J Biotechnol 118: 316-327.

18. Pörtncr R, Bohmann A, Liidemann I, Markl H (1994) Estimation of specific glucose uptake rates in cultures of hybridoma cells. J Biotechnol 34: 237-246.

19. Ozturk SS, Riley MR, Palsson B (1992) Effects of ammonia and lactate on hybridoma growth, metabolism, and antibody production. Biotechnol Bioeng 39: 418-431.

20. Lee YK, Kim SY, Kim KH, Chun BH, Lee KH, et al. (2008) Use of soybean protein hydrolysates for promoting proliferation of human keratinocytes in serum-free medium. Biotechnol Lett 30: 1931-1936.

21. Kino-Oka M, Ogawa N, Umegaki R, Taya M (2005) Bioreactor design fo successive culture of anchorage-dependent cells operated in an automated manner. Tissue Eng 11: 535-545. 